\title{
DOSSIER
}

\section{Homenaje a Gonzalo Suárez Belmont}

El 19 de noviembre del 2014, los Departamentos Académicos de Estudios Generales y Derecho, del Instituto Tecnológico Autónomo de México (ITAM), llevaron a cabo un merecido homenaje al Profesor Gonzalo Suárez Belmont por su trayectoria de 42 años de docencia y compromiso con la institución.

A continuación se reproducen las emotivas palabras del homenajeado, así como los textos que leyeron, en dicho evento, los profesores Raúl Figueroa Esquer y José Manuel Orozco Garibay, ambos del Departamento Académico de Estudios Generales. 